\title{
AN INVESTIGATION ON THE TREATMENT OF TANNERY WASTEWATER BY ELECTROCOAGULATION
}

\author{
Ö. APAYDIN ${ }^{*}$ \\ U. KURT \\ M.T. GÖNÜLLÜ
}

Received: 15/05/08

Accepted: 19/09/08

\author{
Yildiz Technical University \\ Environmental Engineering Department \\ 34349 Beşiktaş-Istanbul, Turkey
}

\begin{abstract}
Treatability by the electro-coagulation (EC) and electro-Fenton (EF) methods have been applied to the tannery wastewater from an organized industrial region consisting mostly of tannery plants and compared with each other in this study. Iron plates were used as the anode and cathode. Electrical current was applied at a value of $33.3 \mathrm{~mA} \mathrm{~m} \mathrm{~m}^{-2}$ for all processes in order to determine the electricity consumptions for chemical oxygen demand (COD) and sulfide removal. The optimal contact duration for each process was discovered at the end of the first five minutes. During the EC process, the removal efficiencies of COD and sulfide were $46 \%$ and $90 \%$, respectively. Electricity consumptions were also obtained as $1.8 \mathrm{kWh} \mathrm{kg}^{-}$ ${ }^{1} \mathrm{COD}$ removed and $27.7 \mathrm{kWh} \mathrm{kg}^{-1}$ sulfide removed. During the EF process, on the other hand, the removal efficiencies of COD and sulfide parameters were $54 \%$ and $85 \%$, respectively, and electricity consumptions were also obtained as $1.5 \mathrm{kWh} \mathrm{kg}^{-1}$ COD removed and $8.3 \mathrm{kWh} \mathrm{kg}^{-1}$ sulfide removed. Furthermore, the removal efficiencies of total Chrome and suspended solids were determined to be $97 \%$ and $70 \%$, respectively.
\end{abstract}

KEYWORDS: Electrocoagulation, Electrofenton, Chrome, Electricity consumption, Iron electrode, Tannery wastewater treatment.

\section{INTRODUCTION}

The characteristics of tannery wastewater vary widely depending on the nature of the adopted tanning process, the amount of water used, the process of hide preservation, the hide processing capacity, and the in-plant measures followed to reduce pollution. Treatment of this wastewater by conventional biological methods is often inadequate to remove pollutants completely, especially ammonia and tannins, the latter being characterized by low biodegradability, which is common in poly-phenolic compounds. Meanwhile, the biological treatment of wastewaters containing resistant and toxic compounds requires a long duration of time (Szpyrkowicz et al., 2005).

Techniques such as EC and electro-flotation, which are based on electrochemical treatment processes, do not require chemical additions. Even though electro-coagulation has reached profitable commercialization, it has received very little scientific attention. This process has the potential to eliminate extensively the disadvantages of the classical treatment techniques (Mollah et al., 2001). When electrochemical reactors operate at a high cell potential and the anodic process occurs in the potential region of water discharge, hydroxyl radicals $(\cdot \mathrm{OH})$ (i.e. strong oxidizing agents which react with most organic pollutants) are generated (Simond et al., 1997). In recent years, there has been growing interest in the electrochemical oxidation of wastewater containing toxic compounds. This technique has been applied successfully to the treatment of different types of wastewaters such as textile effluents (Szpyrkowicz et al., 2001, Chen et al., 2003, Daneshwar et al., 2006), landfill leachate (Lopez et al., 2004, Wu et al., 2004, Deng et al., 2007), olive oil wastewaters (Israilides et al., 1997, Gotsi et al., 2005, Ginos et al., 2006, Kotta et al., 2007), domestic sewage (Vlyssides et al., 2002), and tannery waste 
liquors (Szpyrkowicz et al., 2005, Min et al., 2004, Schrank et al., 2004, Schrank et al., 2005). In particular, in the case of the tannery wastewaters having a good conductivity and a high concentration of chloride ions, electrochemical methods have been reported to be effective as a final polishing step because organic pollutants, ammonium, and sulfide ions are oxidized by a direct anodic process and indirect electrolysis via the electro-generation of active chlorine. The effectiveness of the electrochemical oxidation strongly depends on the experimental conditions and, above all, on the nature of the electrode materials. Up to now, several anodes, such as Ti-Pt, Ti-Ir, Ti-Pt-Ir, Ti-Ta, and Ti alloys, as well as graphite electrodes, have been tested for the electrochemical oxidation of tannery wastewater (Panizza and Cerisola 2004). Furthermore, the electro-coagulation technique was observed to be more effective for the removal of chemical COD than the conventional coagulation and sedimentation process. Soluble metal electrodes like $\mathrm{Al}$ and Fe were found to be very effective compared to insoluble electrodes. Al and Fe ions support to coagulation of colloidal particles (Murugananthan et al., 2004). It has been reported that the EF oxidation process ( $\mathrm{pH} \mathrm{3-4)}$ is able to reduce total organic carbon content by mineralization of organic compounds (Schrank et al., 2004, Schrank et al., 2005). However, the process requires acid consumption to decrease $\mathrm{pH}$ and might make the system invulnerable to corrosion. For these reasons, if the intended removal rate is sufficient, it seems that it would be more convenient to perform the process at the $\mathrm{pH}$ of raw wastewater near neutral $\mathrm{pH}$ level. In this case research, the $\mathrm{pH}$ of wastewater taken from an outlet of an equalization basin in a common treatment plant of the Organized Tannery Industrial Region located in the Tuzla District in Istanbul was 7.4.

The present research was aimed at obtaining experimental data on the feasibility of treatment by two different applications of electrochemical processes to tannery wastewater at the present $\mathrm{pH}$ of the wastewater. The applications were tested in order to search for a pretreatment requirement of the wastewater from a combined treatment plant equalization tank of the Organized Tannery Industries Region in Tuzla-Istanbul (Turkey). Those were simply consisting of $\mathrm{H}_{2} \mathrm{O}_{2}$ oxidant added (EF) and not added cases (EC) of treatment method. This research compares the results from both applications.

The mechanism of EC is extremely dependent on the chemistry of the aqueous medium, especially its conductivity. The mechanism of generating ions by EC can be explained with the example of iron, which was used both the anode and cathode in this study. In an electrolytic system, iron produces iron hydroxide. In the case of iron or steel anodes, two mechanisms for the production of the metal hydroxide have been proposed (Rajeshwar and Ibanez 1997). In the EF process, it is expected that occurs both EC and $\mathrm{H} 2 \mathrm{O} 2$ oxidation processes. Thus, it is hoped that the efficiency of the pollutant removal is high.

In this study, the unit energy demands of the electro-chemical process were calculated from Equation 1:

$\operatorname{UED}(\mathrm{t})=[\mathrm{A} \times \mathrm{V} \times \mathrm{t}] /\left[10 \times \mathrm{C}_{\mathrm{i}} \times \eta_{(\mathrm{t})}\right]$

Where UED for each $\mathrm{m}^{3}$ wastewater is the unit energy demand ( $\mathrm{KWh} \mathrm{kg}^{-1}$ pollutant removed); $\mathrm{C}_{\mathrm{i}}$ is initial pollutant concentration $\left(\mathrm{kg} \mathrm{m}^{-3}\right), \eta$ is pollutant removal efficiency (\%), $\mathrm{t}$ is reaction time (hour), $\mathrm{A}$ is the total current applied (Ampere), and $\mathrm{V}$ is the overall cell voltage (Volt).

\section{MATERIALS AND METHODS}

The samples were taken from the outlet of the equalization basin in the common treatment plant of the Organized Tannery Industrial Region located in the Tuzla quarter of Istanbul, Turkey. The treatment plant receives wastewaters from over one hundred small tannery plants, which are based on both chrome and vegetable tanning. In the plant, there are the following treatment steps: equalization, settling, aerobic activated sludge, and physicochemical treatment by chemical coagulation. The samples were collected in PE containers, transported to the laboratory in one hour and protected at $+4{ }^{\circ} \mathrm{C}$ during the experiments. The composition of the wastewater sample taken was determined as given in Table 1 . The wastewater samples used in this study were taken from the outlet of the equalization basin in the common treatment plant of the Organized Tannery Industrial Region in July 2006. 
Table 1. The characteristics of the wastewater in the equalization basin

\begin{tabular}{lll}
\hline Parameters & Values & Units \\
\hline $\mathrm{pH}$ & 7.4 & - \\
Chloride & 6520 & $\mathrm{mg} \mathrm{l}^{-1}$ \\
Electrical Conductivity & $21.63\left(\right.$ at $\left.20^{\circ} \mathrm{C}\right)$ & $\mathrm{mS} \mathrm{cm}^{-1}$ \\
Sulfide & 440 & $\mathrm{mg} \mathrm{l}^{-1}$ \\
COD & 3700 & $\mathrm{mg} \mathrm{l}^{-1}$ \\
BOD & 1470 & $\mathrm{mg} \mathrm{l}_{5}^{-1}$ \\
Total Chromium & 22 & $\mathrm{mg} \mathrm{l}^{-1}$ \\
Ammonia-N & 180 & $\mathrm{mg} \mathrm{l}^{-1}$ \\
SS & 2690 & $\mathrm{mg} \mathrm{l}^{-1}$ \\
Volatile SS & 1260 & $\mathrm{mg} \mathrm{l}^{-1}$ \\
\hline
\end{tabular}

An experimental set-up consisted of a batch laboratory reactor with a 0.5 I glass beaker equipped with a cathode and anode arranged in parallel was used in this study. Both of the electrodes were made of ferrous metal (dimensions $2.0 \mathrm{~mm} \times 6.0 \mathrm{~cm} \times 7.5 \mathrm{~cm}$ ) and were plunged into tannery wastewater of a 0.4 I working volume. The distance between the electrodes was $6 \mathrm{~cm}$. The total effective electrode area was $45 \mathrm{~cm}^{2}$. Ferrous ions act as coagulation materials in the electro-chemical treatment. On the other hand, the same ions catalytically create hydroxyl radicals to a small extent. The electrodes were connected to a digital DC power supply (GW Instek, GPS $3030 \mathrm{DD}, 0-30 \mathrm{~V}, 0-3 \mathrm{~A}$ ). All of the runs were performed at room temperature. In each run, $400 \mathrm{~cm}^{3}$ of wastewater was placed into the electrochemical cell. Electrolysis was started after the current density was adjusted to the desired value (15.0 watt; 1.5 Ampere, 10 Volt). Electrical current was applied at a value of $33.3 \mathrm{~mA} \mathrm{~m}^{-2}$ for all processes.

During EF process, the duration of maximum contact was extended until the time when there remained no $\mathrm{H}_{2} \mathrm{O}_{2}$ residue. The measurement of $\mathrm{H}_{2} \mathrm{O}_{2}$ was made using the permanganometric method. According to the method, a sample is acidified with sulfuric acid and titrated with a standardized potassium permanganate solution. The concentration of hydrogen peroxide is calculated using the volume and normality of the permanganate solution used.

At the end of the electrochemical reactions, the treated samples were left to settle for $30 \mathrm{~min}$. Analysis was made from the limpid phase. Neither centrifuging nor filtration was performed in this study. All of the chemical analyses were carried out according to the Standard Methods for Examination of Water and Wastewater (APHA 1998). The pH was measured by a Jenway 3040 brand $\mathrm{pH}$ meter.

In this study, experimental EF process $\left(\mathrm{H}_{2} \mathrm{O}_{2}\right.$ doses were 1670,3340 , and $5830 \mathrm{mg} \mathrm{l}^{-1}$, which are equal to $21 \%, 42 \%$, and $74 \%$ of the theoretical $\mathrm{H}_{2} \mathrm{O}_{2}$ dose, respectively) and $\mathrm{EC}$ process on the tannery wastewater were performed at the present $\mathrm{pH}(\mathrm{pH} 7.4)$ for a $33.3 \mathrm{~mA} \mathrm{~m}{ }^{-2}$ electrical current. Experiments were repeated three times and the experimental error was around $3 \%$.

\section{RESULTS}

The amount of $\mathrm{Fe}^{2+}$ to be passed to the solution with 15 watt electrical power during electrochemical charge application is based on Faraday's Law. Of course, the amount of $\mathrm{Fe}^{2+}$ in the solution increases with reaction time, and this phenomenon gives an opportunity for coagulation of suspended and some ionic species in the industrial wastewater.

In the EF or EC process, dissolved ferrous ions originating from the anode change to ferric ions. It is known that ferric ions are a coagulation material and form a sludge with $\mathrm{Fe}(\mathrm{OH})_{3}$. The theoretical concentrations (Faradaic) of the anode material during the process. Settled sludge was burned in an oven in $550^{\circ} \mathrm{C}$ for $15 \mathrm{~min}$, and the inorganic quantities of the settled sludge were determined for both the EC process and EF process. According to these results, the anode material concentrations for the EC process and the EF process were determined. It is observed that the concentration of dissolved Fe(II) ions from the anode does not increase 
linearly depending on the reaction time. Thus, the measured results also indicate the anode efficiency.

In the EC process, $\mathrm{Fe}(\mathrm{II})$ concentrations in the settled sludge of 320,620 , and $1480 \mathrm{mg} \mathrm{I}^{-1}$ were calculated for the end of the first $5 \mathrm{~min}, 10 \mathrm{~min}$, and $30 \mathrm{~min}$, respectively. These results show that the current efficiencies of anode were 98\%,95\%, and $75 \%$ for the end of the first 5 $\mathrm{min}, 10 \mathrm{~min}$, and $30 \mathrm{~min}$, respectively. In the beginning, the ions settled as FeS (Solubility product, $\mathrm{K}_{\mathrm{sp}}$, at $25^{\circ} \mathrm{C}, \mathrm{K}_{\mathrm{sp}}=4.0 \times 10^{-19}$ ). At this time, the color of the sludge was black. Afterward, the $\mathrm{Fe}(\mathrm{II})$ ions settled as $\mathrm{Fe}(\mathrm{OH})_{2}\left(\mathrm{~K}_{\mathrm{sp}}=1.8 \times 10^{-15}\right)$ (Mortimer 1986). In this case, the color of the sludge was green.

In the EF process, Fe(III) concentrations in the settled sludge of 510, 1040, and $1550 \mathrm{mg} \mathrm{I}^{-1}$ were calculated for the end of the first $8 \mathrm{~min}, 17 \mathrm{~min}$, and $25 \mathrm{~min}$, respectively. These results show that the current efficiencies of anode were $98 \%, 97 \%$, and $95 \%$ for the end of first 8 min, $17 \mathrm{~min}$, and $25 \mathrm{~min}$, respectively. $\mathrm{H}_{2} \mathrm{O}_{2}$ oxidizes sulfide quickly, and $\mathrm{Fe}(\mathrm{II})$ is oxidized to $\mathrm{Fe}$ (III) simultaneously. $\mathrm{OH}^{-}$ions diffused into the solution from the cathode, and the ions settled as $\mathrm{Fe}(\mathrm{OH})_{3}\left(\mathrm{~K}_{\mathrm{sp}}=6.0 \times 10^{-38}\right)$ (Mortimer 1986). The color of the settled sludge was brown. According to the values the $\mathrm{K}_{\mathrm{sp}}$, it was determined that the volumetric rate of the sludge of $\mathrm{Fe}(\mathrm{OH})_{3}$ is lower than that of the sludge of $\mathrm{Fe}(\mathrm{OH})_{2}$ and $\mathrm{FeS}$.

These findings show that the current efficiency of the anode decreases based on long reaction times. According to these results, the current efficiency of the anode is higher for the EF process than the EC process. The experimental results of the EC process and EF process are given and evaluated below.

\subsection{Electrocoagulation process}

The change in the $\mathrm{pH}$, pollutant removal efficiency, and electrical power used to remove each unit of pollutants were determined with measurements that were conducted in certain intervals. The results obtained for COD and sulfide are presented in Figure 1 and Figure 2, respectively.

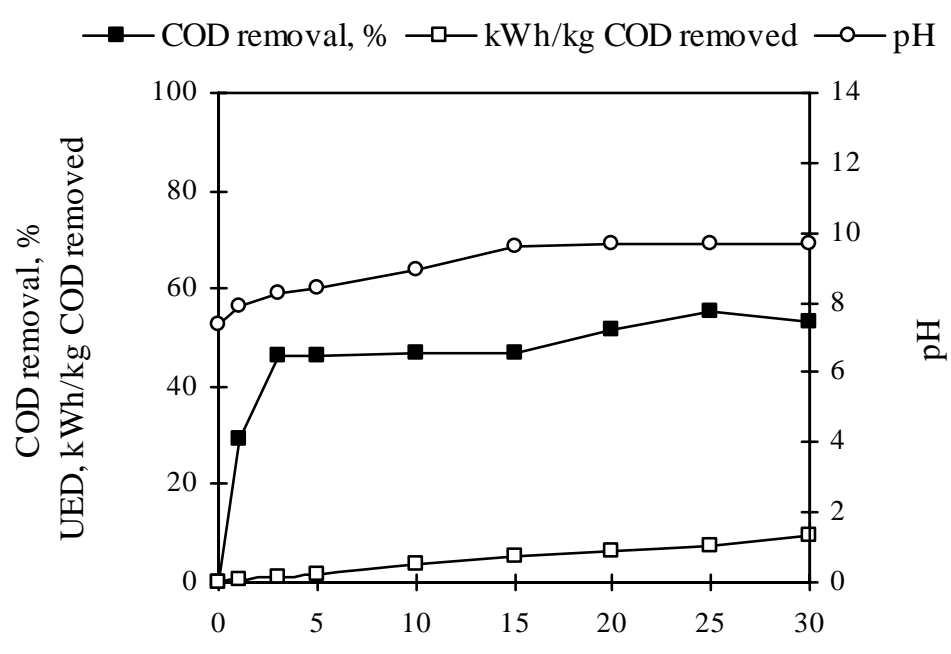

Time, min

Figure 1. $\mathrm{pH}$ development and COD removal during EC experiments

As can be observed in Figure 1, COD removal was about $47 \%$ in the first period of $10 \mathrm{~min}$. In the first $3 \mathrm{~min}$, a value of $1.1 \mathrm{kWh} \mathrm{kg}^{-1}$ COD removed was determined. In the first $20 \mathrm{~min}$, the UED value became $6.5 \mathrm{kWh} \mathrm{kg}^{-1}$ COD removed. COD removal increased from $29 \%$ to $55 \%$ during this process. It is observed from these results that COD removal was at the level of $29 \%$ in the first several minutes; on the other hand, there was an additional increase in COD removal that was necessary to provide additional electrical power. Although the change in 
COD removal was not such an obvious increase, the UED value increased several times more due to the use of electrical energy. This experimental research shows that the electrochemical treatment is efficient for COD removal for the first few minutes, and the subsequent time is neither suitable nor economical for optimal treatment.

Sulfide removal is illustrated in a graphic in Figure 2; it is observed that $25 \%$ of the sulfide was removed by the end of the first $5 \mathrm{~min}$. According to Figure 2, the amounts of required electrical energy for the end of the first 5,10 , and 30 minutes were calculated to be 27.7 , 17.2 , and $43.5 \mathrm{kWh} \mathrm{kg}^{-1}$ sulfide removed, respectively. The first ten minutes are suitable to ensure the efficiency in electrical energy consumption. During the EC experiments, the $\mathrm{pH}$ of tannery wastewater, which was 7.4 at the beginning of the study, increased gradually to 9.2 by the end of $30 \mathrm{~min}$ due to the effect of the cathode reactions. Only about one unit increase $(\mathrm{pH}$ 8.3) was observed in the first $5 \mathrm{~min}$. An increase in the $\mathrm{pH}$ value with time leads to the development of chemical coagulation to remove suspended materials, sulfide, and other pollutants. In the EC applications, the removal efficiencies of SS, total $\mathrm{Cr}$, and Ammonia Nitrogen $\left(\mathrm{NH}_{3}-\mathrm{N}\right)$ were determined to be $70 \%, 97 \%$, and $10 \%$ for 30 min, respectively.

The volumetric and gravimetric amount of sludge formed during the EC process was determined and is given in Table 2. It is observed from Table 2 that the inorganic content increased based on reaction time. In the first $5 \mathrm{~min}$, the organic fractions were measured to be $39.4 \%$ in the process. After that, the organic fractions decreased gradually and went down the value of $20.6 \%$ at the end of $30 \mathrm{~min}$.

$\longrightarrow$ Sulfide removal, \% $-\triangle--\mathrm{kWh} / \mathrm{kg}$ Sulfide removed $-\cdot \mathrm{o}-\cdot \mathrm{pH}$
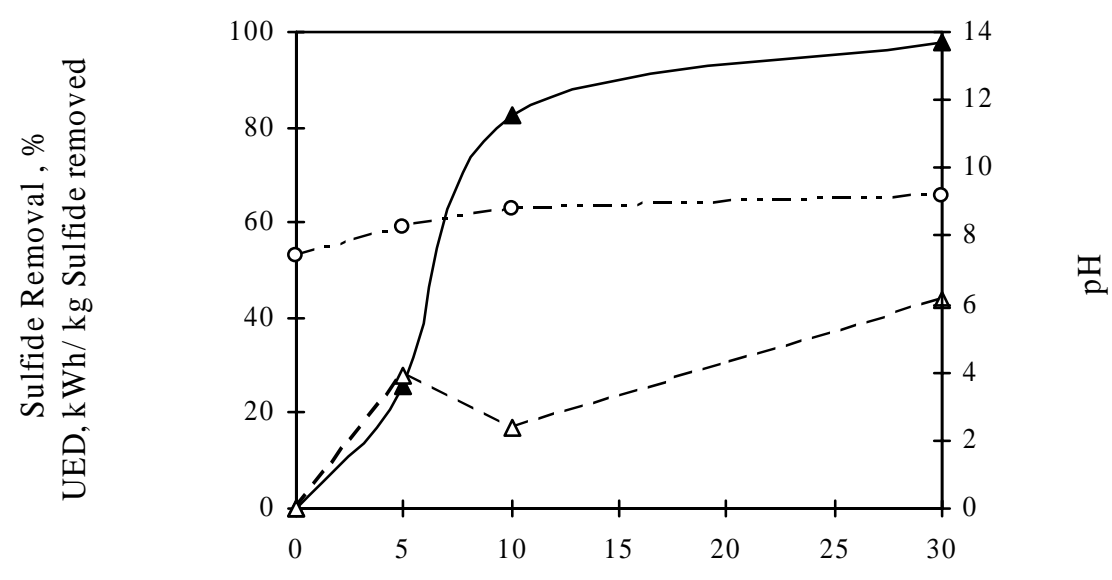

Time, min

Figure 2. Sulfide removals during EC experiments without $\mathrm{H}_{2} \mathrm{O}_{2}$

Furthermore, the gravimetric rates of the sludge increased from 0.33 to $0.86 \mathrm{~g}$ per $100 \mathrm{ml}$ wastewater. The volumetric rates increased also from 13.8 to $23.8 \mathrm{ml}$ per $100 \mathrm{ml}$ wastewater. For comparison, the results obtained for raw wastewater were obtained as $15 \mathrm{ml}$ per $100 \mathrm{ml}$, $0.19 \mathrm{~g}$ per $100 \mathrm{ml}, 53.6 \%$, and $46.4 \%$ for the volumetric rate, gravimetric rate, organic fraction in the solids, and inorganic fraction in the solids, respectively.

\subsection{Electrofenton process}

The EF applications were conducted for 1670,3340 , and $5830 \mathrm{mg} \mathrm{H}_{2} \mathrm{O}_{2} \mathrm{I}^{-1}$ oxidant doses at $33.3 \mathrm{~mA} \mathrm{~m} \mathrm{~m}^{-2}$ electrical current, and $5830 \mathrm{mg} \mathrm{H}_{2} \mathrm{O}_{2} \mathrm{l}^{-1}$ oxidant doses without electrical current at the same $\mathrm{pH}(\mathrm{pH} 7.4)$ as in the previous section. For these oxidant doses, residual oxidant concentrations which remain in the waste water have been illustrated in the graphic in Figure 3. The Figure shows how long the doses applied provide the waste water with $\mathrm{H}_{2} \mathrm{O}_{2}$. This situation also represents the EF process duration. As the dose that is applied increases, 
residual $\mathrm{H}_{2} \mathrm{O}_{2}$ remains in the waste water for a longer time, and therefore it provides more time for the EF process.

Table 2. Sludge formation during Electrocoagulation processes

\begin{tabular}{cccccc}
\hline \multicolumn{2}{c}{$\begin{array}{c}\text { Operational } \\
\text { condition }\end{array}$} & \multicolumn{2}{c}{ Settleable solids } & \multicolumn{2}{c}{$\begin{array}{c}\text { The fractions } \\
\text { in the solids, \% }\end{array}$} \\
\hline $\begin{array}{c}\text { Current, } \\
\mathrm{mA} \mathrm{m}^{-2}\end{array}$ & $\begin{array}{c}\text { Reaction } \\
\text { time, min }\end{array}$ & $\begin{array}{c}\text { Volumetric rate, } \\
\text { ml per 100ml } \\
\text { solution }\end{array}$ & $\begin{array}{c}\text { Gravimetric rate, } \\
\text { g per 100ml } \\
\text { solution }\end{array}$ & Organic & Inorganic \\
\hline 0 & 0 & $15^{(a)}$ & $0.19^{(a)}$ & $53.6^{(a)}$ & $46.4^{(a)}$ \\
33.3 & 5 & 13.8 & 0.33 & 39.4 & 60.6 \\
33.3 & 10 & 17.5 & 0.44 & 33.5 & 66.5 \\
33.3 & 30 & 23.8 & 0.86 & 20.6 & 79.4 \\
\hline
\end{tabular}

(a) Settleable solids in untreated (raw) wastewater

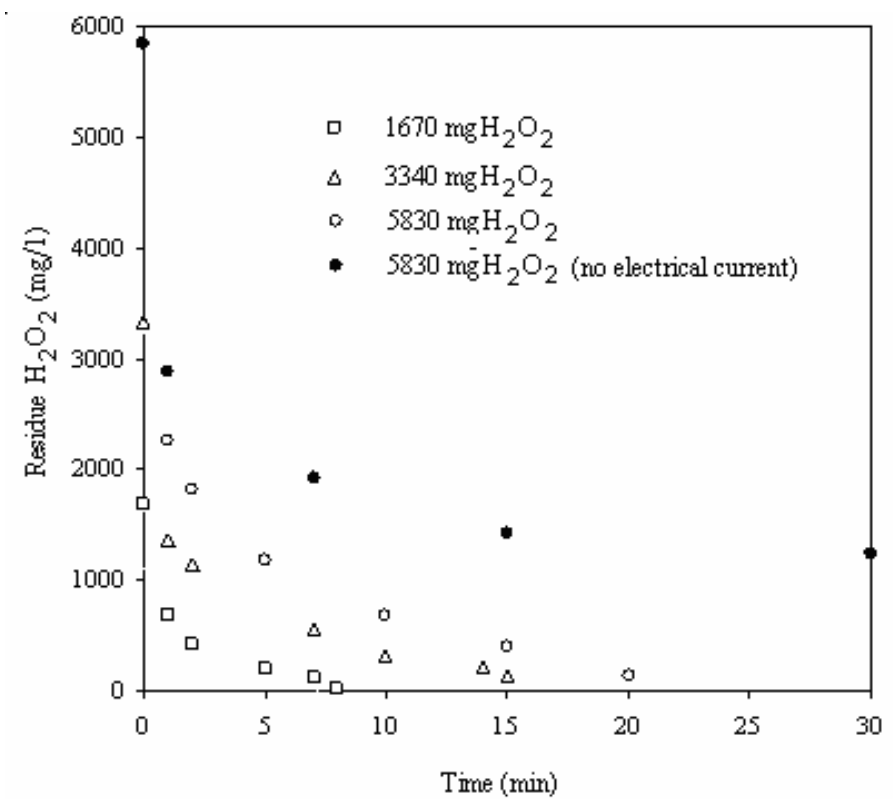

Figure 3. Relationship between $\mathrm{H}_{2} \mathrm{O}_{2}$ dose applied and $\mathrm{H}_{2} \mathrm{O}_{2}$ residue (33.3 mA m ${ }^{-2}$ )

According to Figure 3, the residual oxidant doses in the waste water for 1670,3340 , and 5830 $\mathrm{mg} \mathrm{H}_{2} \mathrm{O}_{2} \mathrm{I}^{-1}$ were measured as $28 \mathrm{mg} \mathrm{H}_{2} \mathrm{O}_{2} \mathrm{I}^{-1}$ (\% 1.67 of $1670 \mathrm{H}_{2} \mathrm{O}_{2} \mathrm{mg} \mathrm{l}^{-1}$, and $8 \mathrm{~min}$ ), 142 $\mathrm{mg} \mathrm{H}_{2} \mathrm{O}_{2} \mathrm{I}^{-1}$ (\% 4.2 of $3340 \mathrm{mg} \mathrm{H}_{2} \mathrm{O}_{2} \mathrm{I}^{-1}$, and $15 \mathrm{~min}$ ), $142 \mathrm{mg} \mathrm{H}_{2} \mathrm{O}_{2} \mathrm{I}^{-1}$ (\% 2.4 of $5830 \mathrm{mg} \mathrm{H}_{2} \mathrm{O}_{2}$ $\mathrm{I}^{-1}$, and $20 \mathrm{~min}$ ), and $142 \mathrm{mg} \mathrm{H}_{2} \mathrm{O}_{2} \mathrm{I}^{-1}$ (\% 2.4 of $5830 \mathrm{mg} \mathrm{H}_{2} \mathrm{O}_{2} \mathrm{l}^{-1}$, and $1200 \mathrm{~min}$ ), respectively. The efficiencies of COD removal were obtained in EF process for different $\mathrm{H}_{2} \mathrm{O}_{2}$ doses. The results show that when the dose applied increases there is a constant increase in COD removal. When a dose of $3340 \mathrm{mg} \mathrm{H}_{2} \mathrm{O}_{2} \mathrm{l}^{-1}$ is applied, the highest removal efficiency (72.4\%) is obtained in $17 \mathrm{~min}$. Removal values obtained with doses that were applied to samples have been evaluated for the contact times mentioned: In the first $5 \mathrm{~min}$; when doses of 1670, 3340, and $5510 \mathrm{mg} \mathrm{H}_{2} \mathrm{O}_{2} \mathrm{I}^{-1}$ were applied, the efficiencies were obtained as $54 \%, 51 \%$, and $49 \%$, respectively. When $\mathrm{H}_{2} \mathrm{O}_{2}$ was not added in the wastewater, the efficiency of COD was determined as $46 \%$. In the first 8 min; when doses of 1670,3340 , and $5510 \mathrm{mg} \mathrm{H}_{2} \mathrm{O}_{2} \mathrm{I}^{-1}$ were applied, the efficiencies were obtained as $64 \%, 60 \%$, and $54 \%$, respectively. When $\mathrm{H}_{2} \mathrm{O}_{2}$ was not added in the wastewater, the efficiency of COD was determined as $47 \%$. In the first 17 min; when doses of 3340 and $5510 \mathrm{mg} \mathrm{H}_{2} \mathrm{O}_{2} \mathrm{I}^{-1}$ were applied, the efficiencies were obtained as $72 \%$ and $65 \%$, respectively. When $\mathrm{H}_{2} \mathrm{O}_{2}$ was not added in the wastewater, the efficiency of COD was determined as $47 \%$. 
In the first 25 minutes; when a dose of $5510 \mathrm{mg} \mathrm{H}_{2} \mathrm{O}_{2} \mathrm{I}^{-1}$ was applied, the efficiency was obtained as $70 \%$. When $\mathrm{H}_{2} \mathrm{O}_{2}$ was not added in the wastewater, the efficiency of COD was determined as $55 \%$.

All of this data obtained for the EC and EF process which shows that an important amount of COD removal is achieved in the few minutes. It is observe that COD removal of over $54 \%$ can be achieved in the first $8 \mathrm{~min}$ in the EF process.. Contact time and electrical energy are important in that process. In the EF process, an additional removal amount of $8 \%$ was achieved compared with the EC process. During the EF process, the electrical energy used for COD removed at different $\mathrm{H}_{2} \mathrm{O}_{2}$ doses was calculated. It is seen clearly from calculation that UED values that were obtained in EF application are lower than the values obtained in EC application.

UED values obtained with efficiencies have been evaluated below for certain contact times. In the first $5 \mathrm{~min}$; in the EF process, when doses of 1670, 3340, and $5510 \mathrm{mg} \mathrm{H}_{2} \mathrm{O}_{2} \mathrm{I}^{-1}$ were applied, UED values were obtained as $1.5,1.6$, and $1.7 \mathrm{kWh} \mathrm{kg} \mathrm{l}^{-1}$ COD removed, respectively. When $\mathrm{H}_{2} \mathrm{O}_{2}$ was not added in the wastewater, the UED was determined as 1.8 kWh kg $\mathrm{I}^{-1}$ COD removed. In the first 8 minutes; when doses of 1670, 3340, and $5510 \mathrm{mg}$

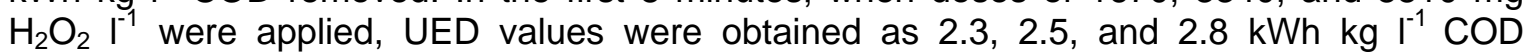
removed, respectively. When $\mathrm{H}_{2} \mathrm{O}_{2}$ was not added in the wastewater, the UED was determined as $3.2 \mathrm{kWh} \mathrm{kg} \mathrm{l}^{-1}$ COD removed. In the first $17 \mathrm{~min}$; when doses of 3340 and 5510 $\mathrm{mg} \mathrm{H}_{2} \mathrm{O}_{2} \mathrm{I}^{-1}$ were applied, the UED values were obtained as 3.9 and $4.4 \mathrm{kWh} \mathrm{kg} \mathrm{l}^{-1}$ COD removed, respectively. When $\mathrm{H}_{2} \mathrm{O}_{2}$ was not added in the wastewater, the UED was determined as $6.1 \mathrm{kWh} \mathrm{kg} \mathrm{l}^{-1}$ COD removed. In the first $25 \mathrm{~min}$; when a dose of $5510 \mathrm{mg}$ $\mathrm{H}_{2} \mathrm{O}_{2} \mathrm{I}^{-1}$ is applied, the UED value was obtained as $5.9 \mathrm{kWh} \mathrm{kg} \mathrm{I^{-1 }} \mathrm{COD}$ removed. When $\mathrm{H}_{2} \mathrm{O}_{2}$ was not added in the wastewater, the UED was determined as $7.6 \mathrm{kWh} \mathrm{kg}^{-1}$ COD removed. According to the results, it can be said that the removal efficiency of the pollutants was higher by $10 \%$ in the EF process than in the EC process. In the first 5 min, significant COD removal was achieved in the EF process. Also, it was observed that energy consumption is at a $20 \%$ lower rate in the EF process than in the EC process.

Sulfide removal is illustrated in Figure 4 ; it is seen that $85 \%$ of the sulfide was removed by the end of the first $5 \mathrm{~min}$.

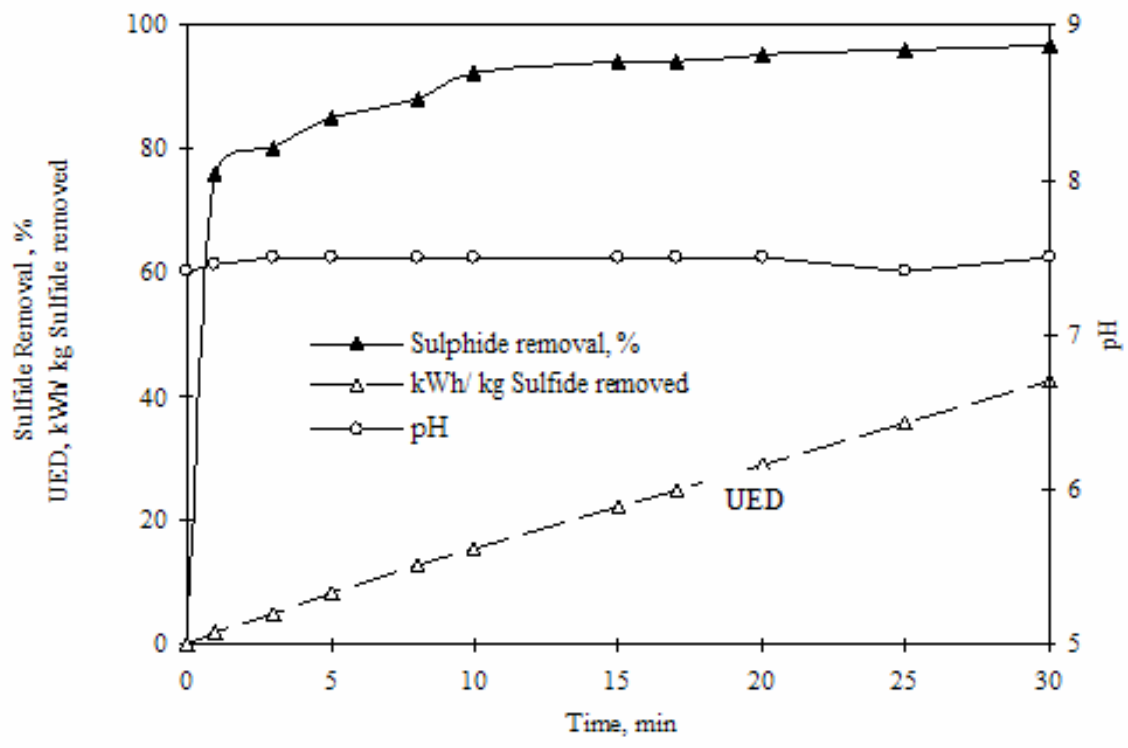

Figure 4. Sulfide removals during EF experiments

According to Figure 4, the values of UED at the end of the first 5, 8, 17, and 25 min were calculated as $8.3,12.6,24.8$, and $35.9 \mathrm{kWh} \mathrm{kg} \mathrm{l}^{-1}$ sulfide removed, respectively. The first few minutes were suitable to ensure the efficiency in electrical energy consumption. A slight increase was observed in $\mathrm{pH}$ value. It was measured as 7.5 at the end of $25 \mathrm{~min}$. In the EF 
applications, the removal efficiencies of $\mathrm{SS}$, total $\mathrm{Cr}$, and $\mathrm{NH}_{3}-\mathrm{N}$ were determined as $70 \%$, $99 \%$, and $10 \%$ for $25 \mathrm{~min}$, respectively.

Flock formations both EC and EF experiments became visible after the $2 \mathrm{~min}$. It was determined that the volume of sludge settled increased in direct proportion with reaction duration and the electrical power applied, as it depends on the presence of iron ions in that environment. The characterization of sludge formed from EF processes is given in Table 3. The volumetric and gravimetric amount of sludge formed during EF process was obtained and is given in Table 3. According to Table 3, the inorganic contents increase based on reaction time. The amount of sludge formed was lower in the EF process than in the EC process. This is because a significant portion of organic matter in the solution was oxidized by $\mathrm{H}_{2} \mathrm{O}_{2}$. In the first $8 \mathrm{~min}$, the organic fractions were determined as 44.2\%. After that, they decreased gradually and went down to $28.1 \%$ by the end of $30 \mathrm{~min}$. Furthermore, the gravimetric rates of the sludge increased from 0.30 to $0.49 \mathrm{~g}$ per $100 \mathrm{ml}$ wastewater. Volumetric rates increased also from 5.0 to $8.8 \mathrm{ml}$ per $100 \mathrm{ml}$ wastewater.

Table 3. Sludge formation during EF processes

\begin{tabular}{cccccc}
\hline \multicolumn{2}{c}{ Operational condition } & \multicolumn{2}{c}{ Settleable solids } & \multicolumn{2}{c}{$\begin{array}{c}\text { The fractions } \\
\text { in the solids, \% }\end{array}$} \\
\hline $\begin{array}{c}\text { Current, } \\
\mathrm{mA} \mathrm{m}^{-2}\end{array}$ & $\begin{array}{c}\text { Reaction } \\
\text { time, min }\end{array}$ & $\begin{array}{c}\text { Volumetric rate, } \\
\text { ml per 100ml } \\
\text { solution }\end{array}$ & $\begin{array}{c}\text { Gravimetric rate, } \\
\text { g per 100ml } \\
\text { solution }\end{array}$ & Organic & Inorganic \\
\hline 0 & 0 & $15^{(\mathrm{b})}$ & $0.19^{(\mathrm{b})}$ & $53.6^{(\mathrm{b})}$ & $46.4^{(\mathrm{b})}$ \\
33.3 & 8 & 5.0 & 0.30 & 44.2 & 58.8 \\
33.3 & 17 & 7.5 & 0.42 & 32.5 & 67.5 \\
33.3 & 25 & 8.8 & 0.49 & 28.1 & 71.9 \\
\hline
\end{tabular}

(b) Settleable solids in untreated (raw) wastewater

\section{DISCUSSION}

In this research, the EF process and the EC process were studied by comparing them at the present $\mathrm{pH}$ (7.4) of tannery wastewater from organized industrial tannery plants. For that purpose, plates made from iron material were used for both the anode and cathode. By five minutes of contact time, optimal removals for both processes were obtained. With the experimental results related in their unit electricity demands (or consumptions), the COD and Sulfide removals indicated that the EF process was more efficient than the EC process.

During the first five minutes of the EC application, electrical consumptions for pollutant removal were found to be $1.8 \mathrm{kWh} \mathrm{kg}^{-1} \mathrm{COD}$ removal and $27.7 \mathrm{kWh} \mathrm{kg}^{-1}$ Sulfide removed. On the other hand, during the same reaction time for EF application, electrical consumptions for pollutant removal were also determined to be $1.5 \mathrm{kWh} \mathrm{kg}^{-1} \mathrm{COD}$ and $8.3 \mathrm{kWh} \mathrm{kg}^{-1}$ Sulfide removed. The results imply that there is a lower energy requirement for the process than the comparable values obtained in the literature. In a study with $\mathrm{pH}$ between 3 and 4 , it was determined that energy requirement was $5.77 \mathrm{kWh} \mathrm{kg}^{-1}$ COD removed for a Ti-Pt anode and Ti cathode (Rao et al., 2001).

Wastewater characteristics of the equalization basin in the common treatment plant of the Organized Tannery Industrial Region change based on time. Characteristics of a sample taken from the equalization basin used in a study (Kurt et al., 2007) were different from the characteristics of the sample used in this study. COD, sulfide, SS, conductivity, and total $\mathrm{Cr}$ concentrations of the present sample were higher than in the other. According to the other study, the removal efficiency of COD was obtained as $60 \%$ at the end of $12 \mathrm{~min}$. However, in the present study, the removal efficiency of COD was obtained as $64 \%$ at the end of 8 minutes. This is a disadvantage of using dissolving type electrodes such as iron and aluminum which are necessary for the removal of sludge. In this study, the reaction times for both the EC process with $\mathrm{H}_{2} \mathrm{O}_{2}$ and the EC process without $\mathrm{H}_{2} \mathrm{O}_{2}$ were between 5 and 30 min. Electrical current used in the processes was $33.3 \mathrm{~mA} \mathrm{~m}^{-2}$. Inorganic content of the sludge increased based on reaction time due to soluble electrodes for the processes. In the first five minutes, inorganic fractions of the sludge in the EF process and in the EC process were 
obtained as $58.8 \%$ and $60.6 \%$, and they increased gradually and went up to $71.9 \%$ and $79.4 \%$ at the end of $30 \mathrm{~min}$, respectively. According to these comparisons, the organic fraction rate of the wastewater increased gradually in the EC processes. At the end of the first $5 \mathrm{~min}$, the organic fractions of the sludge in the EF process and in the EC process were $39.4 \%$ and $44.2 \%$, and they decreased gradually and went down to $28.1 \%$ and $20.6 \%$ at the end of $30 \mathrm{~min}$, respectively. After that, the gravimetric rates of the sludge in the EF process and in the EC process increased from $0.30 \mathrm{~g}$ to $0.49 \mathrm{~g}$ and from 0.33 to $0.86 \mathrm{~g}$ per $100 \mathrm{ml}$ wastewater, respectively. The volumetric rates in the EF process and in the EC process increased also from $5.0 \mathrm{ml}$ to $8.8 \mathrm{ml}$ and from $13.8 \mathrm{ml}$ to $23.8 \mathrm{ml}$ per $100 \mathrm{ml}$ wastewater, respectively.

In the EF applications, the efficiencies of $\mathrm{SS}$, total $\mathrm{Cr}$, and $\mathrm{NH}_{3}-\mathrm{N}$ were determined as $70 \%$, $99 \%$, and 15\%, for 25 min, respectively. These findings compared with the EC applications, the efficiencies of $\mathrm{SS}$, total $\mathrm{Cr}$, and $\mathrm{NH}_{3}-\mathrm{N}$ were also determined as $70 \%, 97 \%$, and $10 \%$, for 30 min, respectively.

\section{CONCLUSION}

It was pointed out that the removal efficiency of the pollutants is $10 \%$ higher in the EF process than the EC process. In the first $5 \mathrm{~min}$, significant COD removal is achieved in the EF process. Also, it was observed that energy consumption is $20 \%$ lower in the EF process than the EC process. Consequently, both the EF process and the EC process show a fast and efficient reaction in the treatment of tannery industry wastewaters. They also enable reduced energy cost and construction of a lower dimensioned treatment facility. Moreover, the $\mathrm{pH}$ was about 7.0 in these processes. Thus, additional chemical substances are not required. At the condition of neutral $\mathrm{pH}$, negative effects such as corrosion of the contact tank are not hoped for in the processes. According to the experimental findings, the EF process can especially be a pre-treatment choice saving time and space that is more effective in the removal of organics.

\section{ACKNOWLEDGEMENTS}

The authors thank the Yildiz Technical University Scientific Projects Coordination Department for monetary support. This research was supported by the Yildiz Technical University Scientific Projects Coordination Department (Project Number: 25/05/02.01).

\section{REFERENCES}

APHA (1998), Standard Methods for the Examination of Water and Wastewater, 20th Ed. Washington, DC.

Chen X., Chen G. and Yue P.L., (2003), Anodic oxidation of dyes at novel Ti-B-diamond electrodes, Chemical Engineering Science, 58, 995-1001.

Daneshvar N., Oladegaragoze A. and Djafarzadeh N., (2006), Decolorization of basic dye solutions by electrocoagulation: An investigation of the effect of operational parameters, Journal of Hazardous Materials, 129, 116-122.

Deng Y., Englehardt J.D., (2007), Electrochemical oxidation for landfill leachate treatment, Waste Management, 27, 380-388.

Ginos A., Manios T., Mantzavinos D., (2006), Treatment of olive mill effluents by coagulationflocculation-hydrogen peroxide oxidation and effect on phytotoxicity, Journal of Hazardous Materials, 133, 135-142.

Gotsi M., Kalogerakis N., Psillakis E., Samaras P., Mantzavinosa D., (2005), Electrochemical oxidation of olive oil mill wastewaters, Water Research, 39, 4177-4187.

Israilides C.J., Vlyssides A.G., Mourafeti V.N. and Karvouni G., (1997), Olive oil wastewater treatment with the use of an electrolysis system, Bioresource Technology, 61, 163-170.

Kotta E., Kalogerakis N., Mantzavino D., (2007), The effect of solids on the electrochemical treatment of olive mill effluents, Journal of Chemical Technology \& Biotechnology, 82, 504511.

Kurt U., Apaydin O. and Gonullu M.T., (2007), Reduction of COD in wastewater from an organized tannery industrial region by electro-Fenton process, Journal of Hazardous Materials, 143, 3340. 
Lopez A., Pagano M., Volpe A. and Di Pinto A.C., (2004), Fenton's pre-treatment of mature landfill leachate, Chemosphere, 54, 1005-1010.

Min K.S., Yu J.J., Kim Y.J. and Yun Z., (2004), Removal of ammonium from tannery wastewater by electrochemical treatment, Journal of Environmental Science and Health Part AToxic/Hazardous Substance \& Environmental Engineering, A39, 1867-1879.

Mollah M.Y.A., Schennach R., Jose R.P. and David L.C., (2001), Electrocoagulation (EC)science and application, Journal of Hazardous Materials, B84, 29-41.

Mortimer C.E., (1986), Chemistry, Wadsworth Publishing Company, California.

Murugananthan M., Bhaskar R.G. and Prabhakar S., (2004), Separation of pollutants from tannery effluents by electro flotation, Seperation. and Purification Technology, 40, 69-75.

Panizza M. and Cerisola G., (2004), Electrochemical oxidation as a final treatment of synthetic tannery wastewater, Water Science and Technology, 38, 5470-5475.

Rajeshwar K. and Ibanez J., (1997), Environmental Electrochemistry Fundamentals and Applications in Pollution Abatement, Academic Press, London.

Rao N.N., Somasekhar K.M., Kaul S.N. and Szyprkowicz L., (2001), Electrochemical oxidation of tannery wastewater, Journal of Chemical Technology and Biotechnology, 76, 1124-1131.

Schrank S.G., Jose H.J., Moreira R.F.P.M. and Schröder H., (2004), Elucitation of the behavior of tannery wastewater under advanced oxidation conditions, Chemosphere, 56, 411-423.

Schrank S.G., Jose H.J., Moreira R.F.P.M. and Schröder H., (2005), Applicability of Fenton and $\mathrm{H} 2 \mathrm{O} 2 / \mathrm{UV}$ reactions in the treatment of tannery wastewaters, Chemosphere, 60, 644-655.

Simond O., Schaller V. and Comninellis C.H., (1997), Theoretical model for the anodic oxidation of organics on metal electrodes, Electrochemistry ACTA, 42, 2009-2012.

Szpyrkowicz L., Juzzolino C., Kaul S.N. and Daniele S., (2000), Electrochemical oxidation of dyeing baths bearing disperse dyes, Industrial Engineering Chemistry Research, 39, 32413248

Szpyrkowicz L., Kaul S.N. and Neti R.N., (2005), Tannery wastewater treatment by electrooxidation coupled with a biological process, Journal of Applied Electrochemistry, 35, 381-390.

Vlyssides A.G., Karlis P.K., Rori N. and Zorpas A.A., (2002), Electrochemical treatment in relation to $\mathrm{pH}$ of domestic wastewater using Ti-Pt electrodes, Journal of Hazardous Materials, B95, 215-226.

Wu J.J., Wu C.C., Ma H.W., Chang C.C., (2004), Treatment of landfill leachate by ozone-based advanced oxidation processes, Chemosphere, 54, 997-1003. 